\title{
SOUTH AFRICA: A NEW DAWN?
}

\section{Vladimir Shubin ${ }^{1}$}

In early July, I99I, the first National conference of the $\mathrm{ANC}^{2}$ after its political admission took place in Durban. There, the party's new leadership was formed, Nelson Mandela was elected ANC President and Walter Sisulu its Deputy President, both unopposed. However, the race for the next top position, that of Secretary-General, did take place and Cyril Ramaphosa, a long-standing leader of the National Union of Miners (NUM), won by good majority over Alfred Nzo who had occupied this post for 22 years.

I had the honor of addressing the conference and, on the way back home, a very fruitful discussion in the ANC Headquarters in Johannesburg with Joe Slovo, then Secretary-General of the South African Communist Party and member of the ANC National Executive Committee. Slovo was quite happy with the results of the conference and in particular with the composition of the NEC3: "We haven't made any canvassing, but it's the best Executive we could have". Comrade Joe, as we usually called him, was of high opinion of the ANC's new Secretary-General: "He is not a member of the SACP4, but we always cooperated well with him". However, Slovo then stopped for a moment and said: "But we remember that before the NUM he worked for Anglo-American Corporation".

These words of Slovo came to my mind when I read about Ramaphosa's election to the post of the President of the ANC in December 20I7 and then of the Republic of South Africa in February 20I8. His road to these high positions was not easy. When, back in I99I, Ramaphosa was elected to the post of ANC Secretary-General, none other than Jacob Zuma became his deputy. Moreover, he was second after Nelson Mandela in the list of ANC candidates in the first democratic elections in I994, and only at the last moment it was decided that the post of deputy president of South Africa would be taken not by him, but by Thabo Mbeki. If this had not happen, he would have every chance

I Institute for African Studies of the Russian Academy of Sciences and Russian State University for the Humanities, Moscow, Russia. E-mail: vlgs@yandex.ru.

2 African National Congress.

3 National Executive Committee, the highest organ of the ANC.

4 South African Communist Party. 
to become the leader of the ANC back in I997, and two years later president of the Republic of South Africa.

For two years, Ramaphosa chaired the Constitutional Assembly, and after the adoption of this most important document, he went to the business world, however remaining a member of the ANC's NEC. Moreover, he was elected in 2012 Deputy President of the ANC and, in 20I4, the country's Deputy President.

Therefore, after the resignation of Jacob Zuma on February I4, 20I9, in accordance with the Constitution of South Africa, Ramaphosa immediately became the acting president and on the next day the National Assembly unanimously elected him president of the Republic of South Africa. Only MPs from the Economic Freedom Fighters party left the chamber at that moment, declaring the illegality of the Parliament, but they also joined the standing ovation after Ramaphosa's "State of the Nation" address the next day.

In his speech, Ramaphosa outlined the program of his government. In essence, it complies with the decisions of the African National Congress (ANC) conference held in December 20I7 and provides for a "radical economic transformation", including the possibility of expropriating land without compensation, but without compromising the economy and food security.

At the end of his speech, Ramaphosa quoted the song of the recently deceased South African composer Hugh Masekela "Thina Mina!" “'Send me!") and ended it with the words: "Now is the time for each of us to say "send me". Now is the time for all of us to work together, in honor of Nelson Mandela to build a new, better South Africa for all".

In addition to the slogan "Thina Mina!", symbolizing the willingness to work for the good of the country, another expression took the most important place in the keynote speech of Ramaphosa - "New Dawn": "We should put all the negativity that has dogged our country behind us because a new dawn is upon us." (Ramaphosa, 20I8).

However, as we know, the dawn comes after night, so how "dark" was South Africa under the rule of the predecessor of Ramaphosa? This expression seems like a poetic exaggeration, but, so to speak, the "dark spots" on the light background were also considerable. In recent years, the economic situation in South Africa has become more complicated. However, the "darkest" side of the last period of "Zuma's rule" was the growth of corruption, and this directly affected the head of state and his relations.

So, the fight against corruption became the main urgent task facing the new president. However, Ramaphosa has been known since the leadership of the NUM as a person who seeks to solve problems through nego- 
tiations and avoid extreme measures. For example, in 2008 he opposed the "recall" of Thabo Mbeki by the ANC's NEC as president, and after the December 20I7 ANC Conference he patiently negotiated with Zuma, trying to achieve his (at least outwardly) voluntary resignation, and even arranged a farewell cocktail party in honor of him and his cabinet (Enca 2018).

Therefore, it is not surprising that Cyril Ramaphosa, to strengthen his position, uses, first of all, not administrative measures, but the country's legal system. The Commission of Inquiry into State Capture, headed by Deputy Chief Justice Raymond Zondo, began working in Pretoria on August 20, 20I8. Zuma, although after many delays, had to agree to form the Commission following the recommendations contained in the report of the then Public Protector Thuli Mandosela, which disclosed the misuse by the state apparatus and state properly, especially by the Gupta brothers who came from India in the early i990s.

According to authorities, in recent years, soo billion rand (about \$ 7 billion) has been stolen through "state capture" and corruption, and the new president intends to return them to the Treasury (Marrian 20I8). At the commission meetings, many facts have been revealed that are harmful to the former president. Although, in accordance with the powers of the commission, information obtained in the course of its work cannot be used as evidence in court, the "normal" South African legal mechanism has again worked with respect to Zuma. Already on April 6, 20I8, he appeared before the High Court in Durban on 16 charges, including fraud, corruption and racketeering (Nair 20I8), with the prosecutor reporting 207 witnesses (Andersen 20I8), although, given South African legal system, it may take many years before his fate is known. For example, at a regular meeting on May 20, 2019, the next meeting was scheduled only for October (Down 20I9).

Moreover, Zuma still has many supporters, first of all, in his native province, KwaZulu-Natal, who gathered near the courthouse with signs saying "Hands off Zuma" and "Iо०\% innocent," and joined him in thinking his "crown” song - "Umshini wami” (“Bring me my machine gun”) (Davis 20I8).

Seeking to restore order in the country's governance system, the new president relies on a number of leaders who held public office until Zuma came to power. For example, the special commission "on the assessment of the mandate, potential and organizational integrity" of South Africa's State Security Agency was headed by Sidney Mufamadi, who served as Minister of Public Security (Police) in Mandela's government, and the report prepared by this commission contained sharp criticism of the activities of the country's special services during Zuma's rule: "A key finding of the panel is that 
there has been political malpurposing and factionalisation of the intelligence community over the past decade or more that has resulted in an almost complete disregard for the Constitution, policy, legislation and other prescripts." (The Presidency 20I9). Another prominent person, Charles Nqakula, who also held that post and then served as Minister of Defense, became the President's security adviser.

As for the economy, Ramaphosa made a public commitment "to generate at least US\$ Ioo billion in new investments over the next five years". To this end, a group of "the President's Special Envoys on Investment" was created that included prominent economists, in particular Msebisi Jonas, who had been removed by Zuma from the post of deputy minister of finance, has already testified against the Guptas (and in effect against the former president) in the Zondo Commission. According to Ramaphosa, "They will be travelling to major financial centres in Asia, Middle East, Europe and the Americas to meet with potential investors"(The Presidency 20I8).

Active work in this direction is carried out by Ramaphosa himself. After Ramaphosa's visit to Saudi Arabia (The Presidency 2018a) and the United Arab Emirates (The Presidency 20I8b), \$ Io billion of investments from each of these countries into the South African economy was announced, and after a visit to China, another \$ I4.7 billion was announced (Hunter 20I8).

On September 2I, 20I8, Ramaphosa announced "the stimulus and recovery plan", consisting

of a range of measures, both financial and non-financial, that will be implemented immediately to firstly ignite economic activity, secondly restore investor confidence, thirdly prevent further job losses and create new jobs, and fourthly to address some urgent challenges that affect the conditions faced by vulnerable groups among our people (The Presidency 20I8).

The central element of this plan was the reprioritization of spending towards activities that have the greatest impact on economic growth, domestic demand and job creation with a particular emphasis on township and rural economies, women and youth (The Presidency 20I8).

The topic of land reform has become extremely sensitive in South Africa in connection with the decision adopted at the ANC National Conference, which provides for the possibility of expropriation of land without compensation. The discussion around the issue was rather hot at the conference and, if to believe press reports, even scuffles broke out inside a closed session (African news agency 20I7). Moreover, one of my old friends, a pro- 
minent South Africa academic shared with me a rather odd version of the events. He believes that the formula "expropriation without compensation" was put forward by Zuma's supporters who hoped it would be rejected at the conference. Then they would leave the hall and no election of a new ANC president would take place.

The adoption of the resolution on "expropriation" was often interpreted in South Africa and especially abroad as a decision to take land from white farmers. However, the caution with which Ramaphosa and his associates intend to carry out land reform was evidenced, for example, by a statement by the national chairman of the ANC, Gwede Mantashe, who suggested that up to I2 thousand hectares be kept in the possession of one farmer (Mahlase 2018).

Moreover, the land issue in South Africa is more complicated. Apart from a crucial lack of land for urban settlements, a highly contested topic is the Ingonyama Trust 5 . It was established to administer the land "traditionally owned by the Zulu people" by an Act of the legislature of the KwaZulu "homeland" on the eve of the I994 general elections. It is controlled by the so-called Zulu King, Goodwill Zwelithini kaBhekuzulu. The High Level Panel on Assessment of Key Legislation and Acceleration of Fundamental Change headed by former president Khalema Motlanthe suggested in its report in $20 I 7$ to repeal the Ingonyama Trust Act (Larc 20I7), but so far no decision was taken on the issue.

The Trust administers 2,8 million hectares (that is almost 30\% of the land in KwaZulu-Natal). The land has to be used "for the benefit, material welfare and social well-being" of the Zulu "tribes and communities" (Larc 20I5), but in reality it remains under control of former apartheid regime's collaborators.

Along with a wide public discussion of this topic, Ramaphosa created the Presidential Advisory Panel on Land Reform and Agriculture. Its members include "highly qualified by virtue of academic knowledge and professional experience, social entrepreneurship or activism related to the agricultural economy and land policy", such as, on the one hand, its chairperson Dr Vuyokazi Mahlati, (female) member of the National Planning Commission and president of the Association of African Farmers of South Africa, and on the other hand, Daniel Kriek, a farmer from the Free State province and president of Agri SA, a federation of agricultural organizations, which calls itself "the keeper of all farmers in, regardless of race, religion

5 Ingonyama, lion in Zulu, is one of the names of the Zulu king. 
or gender" (Agri SA 20I8), but in reality of predominantly white, especially Afrikaner farmers.

The panel produced a detailed (I32 pages) report that in particular suggested:

The different sources of land to address the different demands for land will include different acquisition methods as well as (voluntary) 'donations' from the following:

(a) Churches

(b) The mining houses

(c) Land expropriated from absentee landlords

(d) Municipal land and commonages

(e) Government land not under beneficial use, including land owned by state owned enterprises

(f) Urban landlords

(g) Commercial farmers, including game farmers and foresters

(h) Agribusinesses

(i) Land redistribution farms in distress and close to failure (ADVISORY PANEL ON LAND REFORM AND AGRICULTURE, May 4 2OI9).

By and large, the report was positively received in South Africa. However, it angered the Zulu King. He said that Kgalema Motlanthe's High Level Panel highlighted "the hatred for the Zulu nation" and that the presidential expert advisory panel on land, "also continued to insult him" (Hans 20I9). He threatened to go to court "with the aim of protecting KwaZulu-Natal's rural land which was under the Ingonyama Trust Board's control" in South Africa and outside the borders," It is rather peculiar that he referred to his "friends in Britain" who according to him were also concerned about attempts that were made "against my land". Using the "ethnicity card" he claimed that "this Zuluphobia is aimed at questioning the existence of the Zulu nation." (HANS, Sep. 8 20I9).

In general, it seems that initially, after Ramaphosa came to the presidency, the ANC largely restored the confidence lost during "Zuma's rule". The test of the ANC's influence after the change of its leadership, as well as of other parties, was the May 8, 2019 elections to the national parliament and legislative assemblies of nine provinces of South Africa.

By this time, a rather difficult situation had arisen on the field of political parties in South Africa. Difficulties were notable in the Tripartite 
Alliance in recent years. The leadership of the Communist Party (its number grew to 280 thousand "audited" members in 20I7) (SACP, 20I8) openly advocated the resignation of $\mathrm{Zuma}^{6}$, although several dozens of SACP members were members of parliament, and some, including the General Secretary, Dr Bonginkosi ("Blade") Nzimande, were ministers7.

It is necessary to clarify that they are all elected or appointed to their posts as members of the ANC. But in the last years of Zuma's presidency, proposals to participate in elections independently - and not only in the framework of the Congress - were persistently put forward by the SACP members and especially in the Young Communist League. Criticizing Zuma for refusing to consult with ANC allies on the most important issues, including personnel issues, SACP at its conference in July 2017 raised the question of "reconfiguration" of the tripartite alliance and decided to independently participate in the elections. Moreover, it was tested in practice at the by-elections in November 2017 in one of the municipalities in the Free State Province. The SACP received several mandates there, and after concluding an alliance with the ANC at the local level, her representative became mayor. But in general, this step provoked a negative reaction in the ANC and led to a weakening of the positions of the SACP members in the ANC National Executive Committee: its General Secretary, Chairperson and Deputy Chairperson were not re-elected to it. However, having supported Ramaphosa in the struggle for the highest post, the Communist Party not only did not independently participate in the elections in May 2019, but contributed greatly to the success of the ANC.

There are 400 members in the National Assembly of South Africa, elected according to party lists, and for a party to be represented there it is enough to get just $0.25 \%$ of votes. Therefore, it is not surprising that a record number of parties registered for participation in the 2019 elections (parliamentary and provincial) was 48 (Saho 20I9) (all in all, 6II parties were registered in South Africa, of which 3I4 at the national level, and the rest at the provincial level) (Electoral Commission 20I9a).

To participate in the elections in South Africa, citizens must first register, and out of about 35 million South Africans who had the right to vote, only 26.79 million people did (Electoral Commission 20I9b), but only about

6 Earlier, precisely because of its leadership support to Zuma, a number of the SACP's prominent members had left the party.

7 Shortly before his resignation, Zuma removed Nzimande from the post of Minister of Higher Education and Training, but Cyril Ramaphosa returned him to the cabinet as Minister of Transport, and after the election he was appointed head of the expanded Ministry of Higher Education, Science and Technology. 
two-thirds of them - about I7.76 million - presented themselves at polling stations (Elections 2019).

The election results generally coincided with the forecasts. The ANC gained $57.5 \%$ of the vote (Elections 20I9), significantly less than in the parliamentary elections five years earlier, but more than in the local elections in 20I6. At the same time, the higher share of votes in rural areas of the country was clearly manifested compared to industrial: this party won the highest percentage of votes in predominantly rural Limpopo and Mpumalanga, and the lowest in industrial Western Cape and Gauteng.

The main opponent of the ANC, the Democratic Alliance (DA), gained $20.77 \%$ (Elections, 20I9), that is, less than in 2014 and 20I6. The decrease in the level of support for this party was especially noticeable in its "electoral stronghold" - the province of Western Cape (from 59.4\% in 20 I4 to $52.4 \%$ ). While the change of the top leadership in the ANC, undoubtedly contributed to its success in the elections, one of the reasons for the failure of the DA was precisely the situation in its leadership. Shortly after the 2016 elections, Helen Zille, a white woman who resigned as DA leader giving way to Mmusi Maimane in 20I5, was sharply criticized for speaking out in defense of colonialism. Thereby, considerable damage was done to the desire of the DA to get rid of the image of the party of the white liberals, and Zille was forced to resign from all party posts, although she remained for some time Premier of the Western Cape.

Following this, after allegations of financial misconduct, the mayor of Cape Town, Patricia de Lille, who is coloured, was forced to resign in October 2018 after many months of internal party bickering and even litigation, and then left the DA altogether and announced the creation of a new party with a rather strange name - GOOD Party" (DLULANE, Dec. 2 2018).

De Lille's forced departure weakened the DA's position among coloured people, which make up almost half of the population of Western Cape, and this hardly compensated for the election to the mayor's post of the other colored person, Dan Plato, who had already held this post rather ingloriously.

Unlike the DA, the third most influential party in South Africa, the Economic Freedom Fighters (EFF), improved its results by receiving 10.80\% of the votes (Elections 20I9). It is the only successful party formed in South Africa in recent years, is led by the former head of the ANC Youth League, Julius Malema, who initially actively supported Zuma, and then began to 
criticize him from the "left", and, better to say, from populist positions 8 , advocating "economic freedom" (hence the unusual name of the party) and demanding, in particular, the nationalization of the country's mining industry. It should be noted that Malema himself is not a "proletarian" by the way of life, and the prosecutor's office had charged him for corruption, fraud and racketeering. Besides, serious political accusations were made against the EFF leadership. Baleke Mbete, then speaker of the National Assembly, said: "Those people (EFF) are not working with people of this country alone, they are pawns in a bigger scheme of things where some Western governments are involved" (Mataboge 20I5).

Several "small" parties were created immediately before the elections, and at least the leadership of one of them, the African Transformation Movement (ATM) that won two seats, was associated with Zuma's supporters, and the ANC even convened a commission to investigate the participation of ANC leadership members in the creation of this and other new parties.

As to other "small" parties that got seats in the National Assembly, almost all of them scored less than $\mathrm{I} \%$ of the vote. The exception is the Inkatha Freedom Party $-3.38 \%$ (instead of $2.4 \%$ ) and the Freedom Front Plus (FF + ) $-2.38 \%$ (instead of $0.9 \%$ ) (ELECTIONS, 20I9). The rise in their votes can be explained in the first case by the resignation of Jacob Zuma, a Zulu, and in the second case by the crossing-over of some of the DA supporters9.

The creation of one new party deserves a special attention. In contrast to others, it was initiated by a strong organization, the National Union of Metalworkers of South Africa, that has about 400 thousand members. After harsh criticism of the governmental National Development Plan as a "neoliberal document" the NUMSA's conference decided in 2013 to refuse support for the ANC in the forthcoming elections. The NUMSA leadership announced the creation of several opposition movements initialed the broad-based United Front, the "revolutionary working class" party "based on Marxism-Leninism" and the new nationwide federation of trade unions. The constituent congresses of all three were planned in 20I7, however then only the South African Federation of Trade Unions (SAFTU) consisting of unions that were like NUMSA expelled from SACTU or left it, really began to operate.

8 However, when the author began to characterize the EFF in such a way in a discussion with Khalema Motlanthe, he objected: "No, this is a party of narrow nationalism": this term in the ANC refers to tribalists and black racists (Discussion with K. Motlante, Johannesburg, May 30, 20I8).

9 It is noteworthy that Peter Mare (a coloured), previously a member of the DA and a number of other parties, was nominated as a candidate for the post of premier of the Western Cape from FF +. 
The United Front was moribund, while a new party, practically a competitor to the SACP, was registered in November 2017 under a highsounding name Socialist Revolutionary Workers' Party, but it was completely defeated in the parliamentary elections, gaining only 0.I4\% of the vote (The South African 20I9) (It means that it was supported by no more than $5 \%$ of the members of this union, even less if we take into account members of their families.) However, the schismatic activities of the NUMSA leadership led to a decrease in the ability of trade unions to influence the determination of the country's development course.

A complete disaster was the performance of another "radical" party, "Black First, Land First" that received just o.II \% of votes (The South African 20I9). After the re-election of Ramaphosa and the inauguration that symbolically took place on the Africa Day, the $25^{\text {th }}$ of May, he announced the composition of a new government. The number of portfolios was reduced from 36 to 28 , and according to a principle of gender equality, a $50 \%$ women's quota was introduced.

Key in the conditions of economic turbulence, the post of Minister of Finance was retained by Tito Mboweni, despite the opposition of trade unions. The market, on the contrary, believed that this 6o-year-old professional, who had previously headed the Reserve Bank of South Africa, would be able to strengthen investor confidence and revive the country's economy. The youngest minister was Ronald Lamola, 35, who became the Minister of Justice and Correctional Services. Quite surprisingly, Lindiwe Sisulu was moved to the post of Minister of Human Settlements and Water and the Ministry of International Relations and Cooperation is headed now by Dr Naledi Pandor. A real surprise was the appointment of Patricia de Lille to lead Ministry of Public Works and Infrastructure (South African Government 20I9).

With the high prestige of Cyril Ramaphosa and the ANC's success at the election, it looked like the next five years would be years of implementation of the new president's plans. However, pretty soon South Africa faced new economic and political problems.

The economic situation deteriorated due to a new depreciation of the Rand and the ongoing recession in the economy. Moreover, some days after Ramaphosa's inauguration the governmental Statistics South Africa reported that the economy "slumped sharply in the first three months of 2019 , contracting by $3,2 \%$ with manufacturing, mining and trade the biggest contributors to the fall" (Stats SA 20I9).

Under these conditions, the National Treasury headed by Mboweni suddenly published a paper on "Draft Recovery Strategy" that was critically 
received by many in the ANC and especially among its allies. The SACP Central Committee emphasized in its statement that

The paper incorporates capitalist economic policy reformist prescriptions from the "OECD Economic Surveys: South Africa" and "Economic Policy Reforms 2017: Going for Growth" developed by the elite Organisation for Economic Co-operation and Development (OECD) in 2017 (SACP, Sep. 6 2019).

It continued:

The national democratic sovereignty of our policy space is sacrosanct. The codification of the OECD economic reforms in the "...economic Strategy for South Africa and the process followed in developing and releasing the paper undermined, first and foremost organizationally, the primary mandating role of the ANC-headed Alliance (SACP, Sep. 6 2019).

The paper was resolutely rejected also by the third Alliance member, COSATU: "This Draft Recovery Strategy makes the government appear incoherent, confused and unreliable. COSATU rejects it and demands that National Treasury withdraws this document immediately". It asked quite relevant questions: "What is the status of this document? Why release a document to the public before it has gone to Cabinet? Who will be responsible for it? What if it is divergent to existing policies"? (Pamla 20I9).

The reaction was so critical that the ANC leadership had to meet and issue a statement on September 3 that emphasized the need of discussions in the ANC and its allies:

The meeting resolved that the structures including branches of the ANC should be engaged and be allowed to make comments on the discussion paper.... The meeting agreed that the ANC Alliance should also be allowed to discuss this discussion paper within their structures. The National Officials resolved that the next meeting of the NEC will table the matter for discussion and consider all inputs as stated above (African National Congress 2019).

Moreover personal problems for Ramaphosa and his supporters arose from several sources, in particular from Zondo Commision and Public Protector Busisiwe Mkhwebane. One of the witnesses at the Commission claimed that a number of the ANC leaders received bribes (either by cash 
or by services) from the Bossasa company that provided service to the party. Moreover, Cyril Ramaphosa made a mistake when replying to the question from Mmusi Maimane about 500 thousand rand allocated by this company. He said the money was a payment to his son for the work done, but very soon he corrected himself, admitting that the money was the company's contribution to the CRI7, a campaign for Ramaphosa's election to the ANC Presidency (MAHLATI, Nov. I6 20I8).

However, this incident allowed Mkwebane to accuse Ramaphosa in violation of the constitution and executive ethics code when he "misled" lawmakers about a campaign donation from Bossasa (Bloomberg 2019). Ramaphosa is challenging her findings in court but the case emboldened his opponents within the ANC and hampered his efforts for tighter control over the party. Besides, her office disclosed the sources of donations to CRI7, which included large sums from white-owned companies.

At the same time, Jacob Zuma in his testimony to Zondo Commission and in other public statements accused two prominent ANC members, Ngoako Ramathlodi and Siphiwe Nyanda ${ }^{\mathrm{I}}$ (Dlulane 20I9), who had been appointed by him to ministerial positions in being spies of the apartheid regime. Then, he accused another former minister, Derek Hanekom in being an "enemy agent", but lost the case in Durban high court. It ruled that Zuma's "known enemy agent" tweet about Hanekom was "untrue, defamatory and unlawful" and ordered Zuma to remove it and publish an apology on Twitter within 24 hours as well as to pay damages (Broughton 20I9).

As if these problems were not enough, in the late August and September 20I9 South Africa faced a new disastrous wave of xenophobia directed against African migrants. The ANC, its government and Ramaphosa personally condemned these acts but the image of South Africa suffered a lot, especially on the continent.

As we all know, a dawn cannot be long and a new day comes. What day will it be in South Africa provided Cyril Ramaphosa wins in the inter-ANC struggle and strengthens his party position? There are conflicting opinions about the president's political views. When he was the Secretary General of the National Miners' Union, he openly advocated for socialism, but, as mentioned above, he has become a businessman and one of the richest people in South Africa. When some years ago a journalist asked him if he was still a

Io Siphiwe Nyanda, well known to the author, was second-in-2 in the command of the ANC armed underground machinery in South Africa (famous Operation Vula), Chief of SANDF and then Minister of Communications. He led a group of the ANC military veterans who insisted on Zuma's resignation. 
socialist, he answered: "Yes, I am. But I have coined my own phrase, which in many ways describes what I am. I am a socialist but I operate in a capitalist world. I am therefore a capitalist with a socialist instinct." (Harvey 20I5)

Does Ramaphosa still preserve this instinct? Will it influence his policy? So far, no signs of it; for example, it is hard to believe that the notorious paper was published by the Treasury without his knowledge.

But we still have to wait and see.

\section{References}

Advisory panel on land reform and agriculture (South Africa). Final report of the presidential advisory panel on land reform and agriculture. South Africa, 4 maio 20I9. Available on: https://www.gov.za/sites/ default/files/gcis_document/20I907/panelreportlandreform_I. pdf.

African National Congress. Myanc: statement on the draft economic paper released by treasury. [S. 1.], 3 set. 20I9. Available on: https:// www.ancigI2.org.za/myanc-statement-draft-economic-paper-released-treasury-httpstco6dcnuwfpze.

African news agency (Cape Town). \#ANC54: Scuffles during debate on land redistribution without compensation. Cape Town, 2I set. 2017. Available on: https://www.iol.co.za/news/politics/anc54-scuffles-during-debate-on-land-redistribution-without-compensationI2495088.

Agri SA. Agri SA's key priorities focus on. [S. 1.], 20I8. Available on: https:// www.agrisa.co.za/.

Aandersen, Nic. Zuma trial: State releases names of 207 witnesses testifying, Shaik not listed. South Africa, 29 mar. 20I8. Available on: thesouthafrican.com/news/zuma-trial-state-207-witnesses/.

Bloomberg. Public Protector says Ramaphosa violated the constitution. [S. 1.], I9 jul. 20I9. Available on: https://businesstech.co.za/news/ government/330319/public-protector-says-ramaphosa-violated-the-constitution/.

Broughton, Tania. Zuma loses Hanekom 'spy' defamation case, ordered to pay damages. [S. 1.], 6 set. 20I9. Available on: https://www. timeslive.co.za/news/south-africa/2019-09-o6-zuma-loses-hanekom-spy-defamation-case-ordered-to-pay-damages/. 
Davis, Rebecca. Zuma's Day in Court: Matter postponed to June as cheering crowds pledge loyalty. [S. 1.], 6 abr. 20I8. Available on: https://www. dailymaverick.co.za/article/20I8-04-o6-zumas-day-in-court-matter-postponed-to-june-as-cheering-crowds-pledge-loyalty/.

Dlulane, Bonga. PATRICIA DE LILLE NAMES HER NEW PARTY 'GOOD'. [S. 1.], 2 dez. 20I8. Available on: https://ewn.co.za/20I8/12/o2/patrica-de-lille-names-her-new-party-good.

, Bonga. MKMVA REJECTS ZUMA SPY CLAIMS ON NYANDA, RAMATLHODI. [S. 1.], I6 jul. 20I9. Available on: https://ewn. co.za/2019/07/16/zuma-s-state-capture-allegations-are-irresponsible-says-mkmva.

Down, Aisha Kehoe. Zuma's Trial Postponed After He Petitions to Drop Charges. United Stares, 20 maio 20I9. Available on: https://www. occrp.org/en/27-ccwatch/cc-watch-briefs/9768-zuma-s-trial-postponed-after-he-petitions-to-drop-charges.

Elections (South Africa). National Assembly: Election Results. [S. 1.], 2019. Available on: https://www.elections.org.za/NPEDashboard/app/ mobile.html.

Electoral commission (South Africa) (South Africa). Political party list. South Africa, 2orga. Available on: https://www.elections.org.za/ content/Parties/Political-party-list/.

. Registration Statistics as at I4 Oct 20I9. South Africa, 20Igb. Available on: https://www.elections.org.za/content/Voters-Roll/ Registration-statistics/.

Enca (África do Sul). GALLERY: Zuma in good spirits at farewell cocktail dinner. África do Sul, 20 fev. 20I8. Available on: https://www.enca. com/south-africa/gallery-zuma-in-good-spirits-at-farewell-cocktaildinner.

Hans, Bongani. King Zwelithini slams 'Zuluphobia' as he fights to protect KZN rural land. Cape Town, 8 set. 20I9. Available on: https://www. iol.co.za/news/politics/king-zwelithini-slams-zuluphobia-as-hefights-to-protect-kzn-rural-land-32553522.

Harvey, Ebrahim. Is Ramaphosa still a shoo-in?. [S. 1.], I2 set. 20I5. Available on: https://mg.co.za/article/20I5-o9-Io-is-ramaphosa-still-ashoo-in.

Hunter, Qaanitah. CHINA TO INVEST \$I4.7BN IN SA, SAYS RAMAPHOSA. [S.1.], 24 jul. 20I8. Available on: https://ewn.co.za/2018/07/24/ china-to-invest-usdi4-7bn-in-sa-says-ramaphosa. 
Larc. LAND RIGHTS UNDER THE INGONYAMA TRUST. [S. 1.], fev 2015. Available on: http://www.larc.uct.ac.za/sites/default/files/image_ tool/images/347/FactSheets/FactsheetIngonyama_Final_Feb20I5. pdf. Acesso em: 2 set. 2019 .

. Kgalema Motlanthe's High Level Panel calls for repeal of Ingonyama Trust Act. [S. 1.], 30 nov. 20I7. Available on: https://www. customcontested.co.za/kgalema-motlanthes-high-level-panel-callsfor-repeal-of-ingonyama-trust-act/.

Mahlase, Mahlatse. Land expropriation: Here's how it could be implemented, says Mantashe. Cape Town, I5 ago. 20I8. Available on: https:// www.news 24.com/SouthAfrica/News/land-expropriation-heres-how-it-could-be-implemented-says-mantashe-20I808I5.

Mahlati, Zintle. Ramaphosa confirms R500K Bosasa payment was to fund ANC presidential campaign. [S.1.], I6 nov. 20I8. Available on: https:// www.iol.co.za/news/politics/ramaphosa-confirms-r5ook-bosasa-payment-was-to-fund-anc-presidential-campaign-I8I49588.

Marrian, Natasha. The 'billions siphoned out' through corruption must be recovered, Ramaphosa tells Gauteng ANC members. South Africa, 20 jul. 20I8. Available on: https://www.businesslive.co.za/about/.

Mataboge, Mmanaledi. Mbete: EFF are pawns of the West who want to take over SA. [S. 1.], I4 fev. 20I5. Available on: https://mg.co.za/ article/20I5-02-I4-mbete-eff-are-pawns-of-the-west-who-want-tocontrol-sa.

Nair, Nivashni. Done in 20 minutes: Zuma fraud, corruption case postponed. New York, 6 abr. 20I8. Available on: https://www.timeslive. co.za/news/south-africa/2018-04-o6-done-in-2o-minutes-zumafraud-corruption-case-postponed-to-june/.

Pamla, Sizwe. COSATU Central Executive Committee Statement: $29 \mathrm{Au}$ gust 2019. [S. 1.], 29 ago. 20I9. Available on: http://mediadon. co.za/2019/08/29/cosatu-central-executive-committee-statement-29-august-2019/.

Ramaphosa, Cyril. Discurso do Estado da Nação, 20ı8. Available on: <http:// www.thepresidency.gov.za/state-of-the-nation-address/state-nation-address-president-republic-south-africa\%2C-mr-cyril-ramaphosa>

SACP (South Africa). South African Communist Party. [S. 1.], 20I8. Available on: https://www.sacp.org.za/. 
SACP (South Africa). SACP Augmented Central Committee statement. [S. 1.], 6 set. 2oI9. Available on: https://www.sacp.org.za/content/ sacp-augmented-central-committee-statement-o.

Saho (South Africa). South African General Elections 20I9: List of Political Parties. [S. 1.], 20I9. Available on: https://www.sahistory.org.za/article/south-african-general-elections-20I9-list-political-parties.

South African Government. Government Leaders. South Africa, 20I9. Available on: https://www.gov.za/about-government/leaders.

Stats SA. Economy stumbles in the first quarter. [S. 1.], 4 jun. 2019. Available on: http://www.statssa.gov.za/?p=I2200.

The Presidency (Pretoria). Statement by President Cyril Ramaphosa on launch of new investment drive: I6 April 2018. Pretoria, I6 abr. 20I8. Available on: http://www.dirco.gov.za/docs/speeches/20I8/

- President Ramaphosa lauds his Visit to Saudi Arabia. Pretoria, I3 jul. 20I8a. Available on: http://www.dirco.gov.za/docs/20I8/ saudo7iz.htm.

. State Visit of the President of South Africa to the UAE. Pretoria, I3 jul. 20I8b. Available on: http://www.dirco.gov.za/docs/20I8/ uaeo7I4.htm.

. President Cyril Ramaphosa: Economic stimulus and recovery plan. Pretoria, 2I set. 20I8. Available on: https://www.gov.za/ speeches/president-cyril-ramaphosa-economic-stimulus-and-recovery-plan-2I-sep-20I8-0000.

. President Ramaphosa releases Review Panel Report on State Security Agency. Pretoria, 9 mar. 20I9. Available on: http://www. thepresidency.gov.za/press-statements/president-ramaphosa-releases-review-panel-report-state-security-agency.

The South African. 20I9 Election results: Final totals with all votes counted. [S. 1.], II maio 20I9. Available on: https://www.thesouthafrican.com/news/20I9-south-africa-election-results-national-provincial-all-votes $/$. 


\section{ABSTRACT}

The article analyses recent developments in South Africa after the non-voluntarily resignation Jacob Zuma and election of Cyril Ramaphosa to the post of President of the Republic. One of the key words in his "State of the Nation" report next day after his election were "New dawn": "We should put all the negativity that has dogged our country behind us because a new dawn is upon us. We must leave behind all the negative that prevented our country, because there is a new dawn above us", he said. So the article evaluates the steps the new president took to keep his promise "to turn the country around", and in particular to eradicate widespread corruption. A special attention is paid to the results of the May 2019 national and provincial elections in South Africa.

\section{KEYWORDS}

South Africa; African National Congress; Cyril Ramaphosa; Jacob Zuma; Corruption.

Received on September 13th, 2019 Accepted on September 27th, 2019 